Proc. Estonian Acad. Sci. Biol. Ecol., 2001, 50, 1, 22-32

\title{
THE EFFECT OF CYTOKININ TYPE AND CONCENTRATION AND THE NUMBER OF SUBCULTURES ON THE MULTIPLICATION RATE OF SOME DECORATIVE PLANTS
}

\author{
Rael VARDJA and Tõnis VARDJA \\ Institute of Experimental Biology, Estonian Agricultural University, Instituudi tee 11, 76902 \\ Harku, Harjumaa, Estonia \\ Received 30 November 1999, in revised form 21 November 2000

\begin{abstract}
Long-term micropropagation of some plants by tissue culture was investigated. The plants studied can be divided into three groups according to their sensitivity to cytokinins benzyladenine (BA) and kinetin (K). (1) Plants (gerbera cultivars) whose multiplication on BA media is not recommended. Permanent high $\mathrm{K}$ level must also be avoided. It must be decreased gradually during a long-term culture. After the 8th or 9th subculture the shoots are to be transferred to the resting medium with $0.1 \mathrm{mg} / \mathrm{L} \mathrm{K}$ and $1.0 \mathrm{mg} / \mathrm{L}$ indoleacetic acid. (2) Plants (Cordyline, Dracaena, Dieffenbachia) that may be multiplied on media containing either BA or K, the latter being preferable as its concentration may be varied within a larger range $(0.5-4 \mathrm{mg} / \mathrm{L})$ without negative side effects. (3) Plants (Philodendron, Spathiphyllum, Musa) that may be multiplied on BA media without even relatively high BA concentrations $(5 \mathrm{mg} / \mathrm{L})$ leading to vitrification. However, in order to obtain the best shoots for rooting, the BA content of the multiplication media
\end{abstract} \\ has to be reduced to $1 / 2-1 / 3$ of its original value after the 5 th or 6 th subculture.
}

Key words: decorative plants, tissue culture, long-term micropropagation, cytokinins.

Nutrient media, including their mineral constituents, carbohydrate content, and qualitative and quantitative aspects of growth regulators play an important role in micropropagation.

Plant propagation by tissue culture is usually aimed at the possibly highest multiplication rate (Jámbor-Benczúr \& Márta-Riffer, 1990) without vitrification and mutations. In order to obtain high multiplication rates, relatively large amounts of cytokinins are used in multiplication media. However, in the micropropagation of some plants the multiplication rate decreases with increasing the concentration of cytokinins in the medium (Corchete et al., 1997). In the 
micropropagation of numerous plants, benzyladenine (BA) is much more effective than kinetin $(\mathrm{K}), \mathrm{N}^{6}$-(2-isopentenyl)adenine (2iP), and zeatin (Z) (Evaldsson \& Welander, 1985; Wong, 1986); but unfortunately BA is also an inducer of vitrification (Declerck \& Korban, 1995; Shibli et al., 1997). To avoid vitrification and mutations, BA and $\mathrm{K}$ are replaced by more expensive $2 \mathrm{iP}$ or $\mathrm{Z}$ whose application, as a rule, has not led to these effects. So, for instance, Voyatzi \& Voyatzis (1989) use 2iP in a six times higher concentration than that of K in Dieffenbachia multiplication medium. A. Egedys (pers. comm.) applies 2iP for the multiplication of Spathiphyllum $(10 \mathrm{mg} / \mathrm{L})$ and Syngonium $(20 \mathrm{mg} / \mathrm{L})$. However, Z may cause vitrification of Vaccinium species (Shibli et al., 1997) and $2 \mathrm{iP}$ mutations at the micropropagation of Syngonium (our unpublished results). Omission of BA from the medium even for only one passage enabled to reduce the vitrification of Prunus tenella almost twice (Bouza et al., 1992).

During long-term growth of plants on a medium of the same composition, a decrease or an increase in their proliferation potential could be observed (Nagakubo et al., 1997). Norton \& Norton (1986) were not able to restore the potential by subsequent modifications in the medium of the rosaceous plants investigated (six species).

In this work we studied the influence of modifications of nutrient media during the micropropagation cycle of various decorative plants. Some of these modifications proved to be efficient in avoiding negative phenomena often observed during long-term propagation (about six years).

\section{MATERIALS AND METHODS}

In our experiment we used the following decorative plants: Cordyline terminalis (3 cultivars), Dieffenbachia sp., Dracaena draco, Gerbera jamesonii (17 cultivars), Musa paradisica, Philodendron (2 species.), and Spathiphyllum (3 cultivars). The plants were propagated for commercial purposes.

After the preparatory stage the plant material was washed in running water for $30 \mathrm{~min}$. The material was sterilized as described by Vardja \& Vardja (1995). Depending on its character, the initial material (leaves, buds, shoot segments, flower stalk, etc.) was shaken in 70 to $96 \%$ ethanol for 10 to $60 \mathrm{~s}$, sterilized for 10 to $30 \mathrm{~min}$ in 6 to $9 \%$ solution of freshly prepared and filtered chlorinated lime or chloramine with some drops of Tween- 80 as a detergent, thereafter washed three times with sterilized distilled water, and after removal of injured tissues at a length or width of $0.5 \mathrm{~cm}$, the material was laid onto the initiation medium (Vardja, 1997). Modified Murashige \& Skoog (1962) basic medium (MS), Linsmaier \& Skoog (1965) basic medium (LS), and Knop (1865) medium were used for shoot micropropagation (Table 1).

The cultures were grown in $200-\mathrm{mL}$ culture jars containing $40 \mathrm{~mL}$ of nutrient medium with six explant per jar. In each treatment ten jars were used for 
Table 1. Media used for micropropagation

\begin{tabular}{|c|c|c|c|c|c|}
\hline Species & Stage & $\begin{array}{c}\text { Basal } \\
\text { medium }\end{array}$ & $\begin{array}{c}\text { Mineral supplement, } \\
\mathrm{mg} / \mathrm{L}\end{array}$ & $\begin{array}{l}\text { Organic supplement, } \\
\mathrm{mg} / \mathrm{L}\end{array}$ & $\begin{array}{c}\text { Hormonal } \\
\text { composition, } \mathrm{mg} / \mathrm{L}\end{array}$ \\
\hline \multirow[t]{3}{*}{ Gerbera cv. } & I & MS & $\mathrm{NaH}_{2} \mathrm{PO} \cdot \mathrm{H}_{2} \mathrm{O}(85)$ & \multicolumn{2}{|c|}{$\mathrm{B}_{1}(15) ; \mathrm{B}_{6}(1.0) ; \mathrm{PP}(10) \mathrm{K}(6.0-2.0)$} \\
\hline & III & $1 / 2 \mathrm{MS}$ & & Sacc. $(3 \%) ; B_{1}(0.1)$ & IBA $(1.0)$ \\
\hline & IV & $\begin{array}{l}\text { Knop + MS- } \\
\text { micro }\end{array}$ & & Sacc. $(4 \%) ; B_{1}(0.4)$ & IAA (1.0): K (0.1) \\
\hline Cordyline & I & LS & $\mathrm{NaH}_{2} \mathrm{PO} \cdot \mathrm{H}_{2} \mathrm{O}(170)$ & Ads (80); Sacc. (3\%) & IAA $(0.5)$ \\
\hline Dieffenbachia & & LS & $\mathrm{NaH}_{2} \mathrm{PO} \cdot \mathrm{H}_{2} \mathrm{O}(170)$ & Ads (80); Sacc. (3\%) & $\mathrm{K}(1.0-4.0)$ \\
\hline \multirow[t]{3}{*}{ Dracaena } & & LS & $\mathrm{NaH}_{2} \mathrm{PO} \cdot \mathrm{H}_{2} \mathrm{O}(170)$ & \multicolumn{2}{|l|}{ Ads (80); Sacc. (3\%) } \\
\hline & II & LS & & Sacc. $(3 \%)$ & $\begin{array}{l}\text { K }(0.05-0.1): \text { IAA } \\
(0.5)\end{array}$ \\
\hline & III & $1 / 2 \mathrm{LS}$ & & Sacc. $(2 \%)$ & IAA $(0.5)$ \\
\hline Musa & I & MS & $\mathrm{NaH}_{2} \mathrm{PO} \cdot \mathrm{H}_{2} \mathrm{O}(85)$ & Sacc. $(3 \%)$ & $\mathrm{BA}(5-10)+\mathrm{IAA}(0.1)$ \\
\hline Philodendron & & MS & $\mathrm{NaH}_{2} \mathrm{PO} \cdot \mathrm{H}_{2} \mathrm{O}(85)$ & Sacc. $(3 \%)$ & $\mathrm{BA}(2-4)+\mathrm{IAA}(0.1)$ \\
\hline \multirow[t]{3}{*}{ Spathiphyllum } & & MS & $\mathrm{NaH}_{2} \mathrm{PO} \cdot \mathrm{H}_{2} \mathrm{O}(85)$ & Sacc. $(3 \%)$ & $\mathrm{BA}(1-2)+\mathrm{IAA}(0.1)$ \\
\hline & II & LS & & Sacc. $(3 \%)$ & $\mathrm{K}(0.1) ; \mathrm{IAA}(1.0)$ \\
\hline & III & $1 / 2 \mathrm{LS}$ & & Sacc. $(3 \%)$ & IAA (1.0) \\
\hline
\end{tabular}

I, multiplication; II, elongation; III, rooting; IV, storage or resting; Ads, adenine sulphate; $\mathrm{B}_{1}$, thiamine $\cdot \mathrm{HCl} ; \mathrm{B}_{6}$, pyridoxin $\cdot \mathrm{HCl}$; $\mathrm{PP}$, nicotinic acid; IAA, indoleacetic acid; IBA, indolebutyric acid; Sacc., saccharose.

counting and measuring. The mean multiplication rate was calculated as the number of shoots and buds per initial shoot at the end of each multiplication cycle (4-5 weeks depending on cultivar). The length of shoots and the number of shoots suitable for rooting (high-grade) were also recorded.

Jars were closed with aluminium foil. Fluorescent lamps were used for illumination. The intensity of illumination was $15-60 \mu \mathrm{Mm}^{-2} \mathrm{~s}^{-1}$ at the multiplication and elongation stages and $70 \mu \mathrm{Mm}^{-2} \mathrm{~s}^{-1}$ at the rooting stage. The temperature in a phytotron was $23 \pm 1{ }^{\circ} \mathrm{C}$.

\section{RESULTS}

\section{Gerbera}

Cytokinins play a crucial role in the morphogenesis of gerbera. Addition of $10 \mathrm{mg} / \mathrm{L} \mathrm{BA}$, as compared with $\mathrm{K}$, increased the formation of adventitious buds of all cultivars at both the initiation and the multiplication stage. The number of adventitious buds depended on the plant genotype. Explants of 'Marleen' formed 14.8 buds on the initiation medium containing BA, 13.2 buds with $\mathrm{K}$; those of 'Victoria' formed 11.8 and 2.2 buds, respectively. As a rule, after 4-5 weeks on 
the media, the explants had 2-3 times more buds on BA-media than on $\mathrm{K}$-containing media. In the case of prolonged culture on the initiation media, the number of new buds continued to increase. However, most of the cultivars did not form shoots on media with BA, and some of the cultivars developed vitrification. No vitrification was observed on media with $\mathrm{K}$, and part of the buds formed shoots on the these media.

The effect of BA in the initiation medium became evident already in the first subculture. The material obtained from an initiation medium containing BA formed fewer high-grade shoots suitable for rooting (Table 2) than the material from K-containing media.

The multiplication rate of gerbera was occasionally very high, up to 30 shoots, depending on the cytokinin content of the medium. At equal concentrations of $\mathrm{BA}$ and $\mathrm{K}$, the multiplication rate on media with BA exceeded that on $\mathrm{K}$ twice and more. On media containing BA, vitrification of shoots could be observed during the first subcultures (Table 2).

Table 2. Multiplication rate (A), yield of high-grade shoots (B), and formation of normal (n) and some vitrified or abnormal (v) shoots of gerbera on the first multiplication medium (stage II; $\mathrm{K} 6 \mathrm{mg} / \mathrm{L}$ ). The previous initiation medium (stage I) contained $10 \mathrm{mg} / \mathrm{L} \mathrm{BA}$ or K

\begin{tabular}{|c|c|c|c|c|c|c|c|c|}
\hline \multirow{2}{*}{ Cultivar } & Stage I BA & \multicolumn{2}{|c|}{ Stage II } & \multirow{2}{*}{$\begin{array}{l}\text { Shoots } \\
\text { formed }\end{array}$} & \multirow{2}{*}{$\frac{\text { Stage I K }}{\mathrm{A}}$} & \multicolumn{2}{|c|}{ Stage II } & \multirow{2}{*}{$\begin{array}{l}\text { Shoots } \\
\text { formed }\end{array}$} \\
\hline & A & A & $\mathrm{B}$ & & & A & $\mathrm{B}$ & \\
\hline Marleen & $14.8 \pm 1.2$ & $12.3 \pm 0.8$ & $1.7 \pm 0.6$ & $\mathrm{v}$ & $12.2 \pm 0.5$ & $10.2 \pm 1.0$ & $10.2 \pm 0.4$ & $\mathrm{n}$ \\
\hline Red Marleen & $12.0 \pm 1.3$ & $9.6 \pm 0.5$ & $2.2 \pm 0.3$ & $\mathrm{n}$ & $6.2 \pm 0.5$ & $6.1 \pm 0.1$ & $6.1 \pm 0.2$ & $\mathrm{n}$ \\
\hline Victoria & $11.1 \pm 1.3$ & $5.3 \pm 0.5$ & $1.0 \pm 0.4$ & $\mathrm{v}$ & $2.2 \pm 0.2$ & $3.9 \pm 0.1$ & $3.9 \pm 0.2$ & $\mathrm{n}$ \\
\hline Lydi & $8.9 \pm 0.8$ & $6.3 \pm 0.4$ & $2.1 \pm 0.2$ & $\mathrm{n}$ & $1.8 \pm 0.2$ & $2.4 \pm 0.1$ & $2.4 \pm 0.1$ & $\mathrm{n}$ \\
\hline
\end{tabular}

The multiplication rate of gerbera shoot cultures stayed in the range from 4 to 6. Some double-flowered cultivars had, as a rule, smaller leaves allowing the multiplication rate to increase up to 10 . At excessive multiplication of largeflowered cultivars their leaves began to shadow each other, leading to an increase in vitrification.

At a continuous multiplication of gerbera cultures on high-K $(6 \mathrm{mg} / \mathrm{L})$ media, the multiplication rate of most of the cultivars began to increase starting from the 3rd subculture, reached its maximum in the 4th to 5th (6th) subculture, and thereafter started to decline. Vitrification of numerous cultivars was observed. Such changes in multiplication were observed with all cultivars investigated. Reduction in $\mathrm{K}$ content to $4 \mathrm{mg} / \mathrm{L}$ beginning with the 4 th subculture and to $2-3 \mathrm{mg} / \mathrm{L}$ beginning with the 7 th subculture allowed us to maintain the multiplication at the optimum level for two subcultures (Fig. 1). Starting from the 9th subculture, a large number of abnormal leaves, often with brown spots, were formed. This phenomenon has also been observed in the case of other plant species 


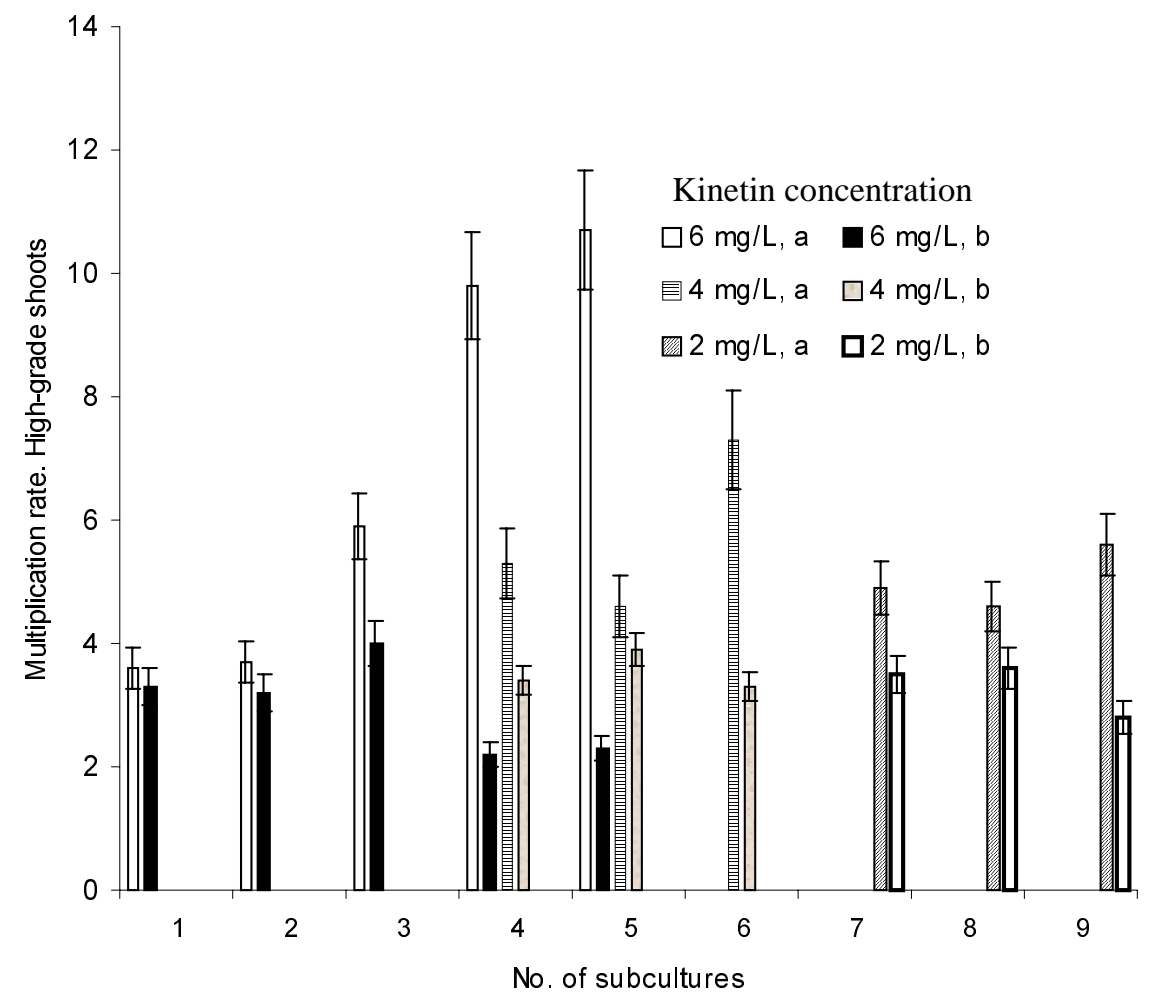

Fig. 1. Effect of kinetin concentration and the number of subcultures on shoot proliferation (a) and shoot quality (high-grade shoots) (b) of the gerbera variety 'Victoria'. Error bars show the standard error of the mean.

(carnation, gypsophila, pear, etc.). It is caused, besides cytokinin accumulation in the culture, by the accumulation of excess mineral elements, particularly $\mathrm{NH}_{4}{ }^{+}$, in the plant (Bouza et al., 1992; A. N. Lavrent'eva, pers. comm.). In order to maintain viability, the culture was transferred to the resting medium with MS macroelements of half strength or to Knop medium with MS microelements.

Plants were separately planted onto the resting medium after pruning (leaves were reduced to $1-1.5-\mathrm{cm}$ petioles). Two transfers at a $3-4$ week interval followed. Cultures did not proliferate on this medium; however, the leaves grew. This enabled selection before a new propagation cycle.

\section{Cordyline spp., Dracaena sp., Dieffenbachia sp.}

Tissue cultures of these species revealed a similar tendency at the propagation: an increase in the content of cytokinins led to an increase in the multiplication rate and to a decrease in shoot length (Fig. 2). Already $2 \mathrm{mg} / \mathrm{L} \mathrm{BA}$ resulted in vitrification of shoots. Therefore, BA cannot be recommended for the 


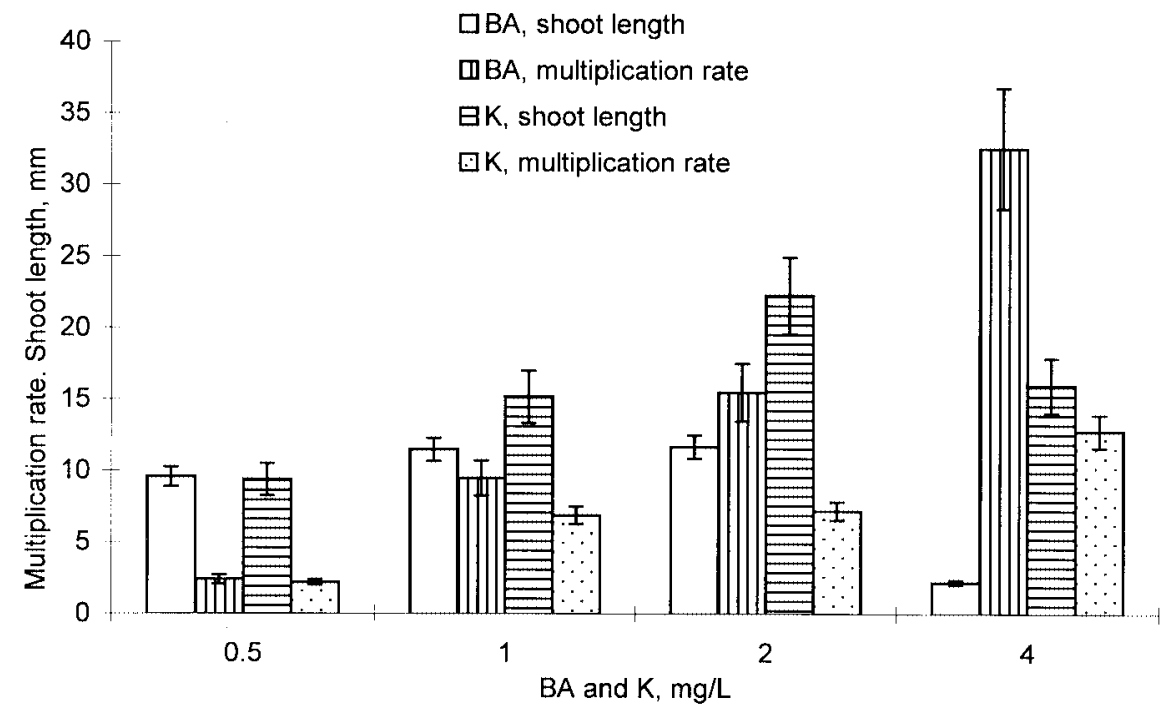

Fig. 2. Shoot length and multiplication rate of Cordyline terminalis cv. Prince Albert on media with different $\mathrm{BA}$ and $\mathrm{K}$ concentrations (3rd subculture after initiation; previous subcultures $2 \mathrm{mg} / \mathrm{L} \mathrm{K}$ ). All media contain $0.5 \mathrm{mg} / \mathrm{L}$ IAA. Error bars show the standard error of the mean.

propagation of these plants by tissue culture. Although $1 \mathrm{mg} / \mathrm{L}$ BA resulted in good proliferation and formation of long shoots, during a long-term culture on media with BA both the rooting of the shoots and the effect of elongation media decreased. At the micropropagation of this plant group by tissue culture no significant changes in the multiplication of the cultures (cf. gerbera) were observed when $1-2 \mathrm{mg} / \mathrm{L} \mathrm{K}$ was used in the multiplication medium. If needed, $\mathrm{K}$ content may be increased up to $4 \mathrm{mg} / \mathrm{L}$ for at least one subculture.

A clump of relatively short shoots was formed on the multiplication medium. These shoots did not root well on rooting media. During prolonged ( 8 weeks) cultivation on the multiplication medium some of the shoots became elongated; however, new microshoots and buds kept on forming. In order to break multiplication and to promote elongation of the shoots already formed, the shoots in clumps (according to their length) were planted onto elongation media. Depending on the species, 3-5-cm-long shoots suitable for rooting formed in 3-4 weeks. They were either transferred onto a sterile rooting medium, or the fresh liquid rooting medium was poured onto the previous elongation medium, or rooting was performed ex vitro.

Maene \& Debergh (1985) suggest that multiplication be stopped by pouring the elongation medium onto the culture instead of transferring the tissues to a new medium. This method reduces manual labour and the cost of the plants significantly. It is successful, however, only if the pouring is not delayed it should be done when there is no apical dominance yet (3rd to 4th week of 
multiplication). When the procedure is performed later, the yield of uniform and sufficiently elongated shoots is less than in the case of transfer onto a new medium (Table 3).

Table 3. Yield of Cordyline shoots suitable for rooting per cultivation vessel after 4-week subculture on a solid elongation medium or in a liquid elongation medium poured on the previous multiplication medium

\begin{tabular}{l|cc|c|c|c|c}
\hline \multirow{2}{*}{$\begin{array}{c}\text { Species, } \\
\text { cultivar }\end{array}$} & $\begin{array}{c}\text { No. of } \\
>2.5-\mathrm{cm} \\
\text { shoots }\end{array}$ & $\begin{array}{c}\text { Length } \\
\text { of }>2.5-\mathrm{cm} \\
\text { shoots }\end{array}$ & $\begin{array}{c}\text { No. of } \\
<2.5-\mathrm{cm} \\
\text { shoots }\end{array}$ & $\begin{array}{c}\text { No. of } \\
>2.5-\mathrm{cm} \\
\text { shoots }\end{array}$ & $\begin{array}{c}\text { Length of } \\
>2.5-\mathrm{cm} \\
\text { shoots }\end{array}$ & $\begin{array}{c}\text { No. of } \\
<2.5-\mathrm{cm} \\
\text { shoots }\end{array}$ \\
\hline $\begin{array}{c}\text { C. terminalis } \\
\text { Lord Robertson }\end{array}$ & $54.7 \pm 4.8$ & $6.2 \pm 0.6$ & $12.6 \pm 5.2$ & $38.3 \pm 4.4$ & $3.6 \pm 0.7$ & $40.1 \pm 9.3$ \\
Prince Albert & $58.3 \pm 3.6$ & $6.3 \pm 0.5$ & $12.1 \pm 4.2$ & $37.2 \pm 5.0$ & $4.1 \pm 1.2$ & $44.7 \pm 7.2$ \\
C. rubra & $51.2 \pm 5.5$ & $5.1 \pm 0.6$ & $12.8 \pm 6.3$ & $35.5 \pm 5.3$ & $4.2 \pm 0.5$ & $45.6 \pm 10.1$
\end{tabular}

Philodendron spp., Spathiphyllum spp., Musa sp.

The multiplication rate of philodendrons may reach a very high value. Jámbor-Benczúr \& Márta-Riffer (1990) obtained a multiplication rate of 39 for $P h$. tuxlanum in the 2nd subculture after the initiation. These investigators used $10 \mathrm{mg} / \mathrm{L} \mathrm{BA}$ in the medium (the mineral constituents of the medium differed from ours). They observed a somewhat greater shoot length as compared with the first subculture as well, but there are no data on the shoot quality.

Our results showed that even $4 \mathrm{mg} / \mathrm{L}$ BA was too much already in the 4 th and 5th subcultures. The multiplication rate increased indeed, but the number of shoots suitable for rooting or planting (over $2 \mathrm{~cm}$ ) decreased. Reduction of the BA content to $2 \mathrm{mg} / \mathrm{L}$ in the 6th and 7 th subcultures led to a decrease in the multiplication rate and to an increase in the yield of well-developed (over $2 \mathrm{~cm}$ ) shoots (Fig. 3). The remaining shoots and plants were relatively long but filamentous, with a couple of small leaves at the top.

Most philodendron shoots formed roots or pneumatophore roots already on the multiplication medium. Therefore, even small plantlets could be planted straight into the substrate for acclimatization. However, their survival rate was low - below 50\% in the case of Ph. erubescens. Clumps of small shoots (5-8 each) transplanted onto the elongation medium gave practically $100 \%$ normal, mostly rooted, plants in 4 weeks. If the share of nonrooted plants reaches 20-30\%, we suggest pouring the rooting medium onto the elongation medium 1-2 weeks prior to their transplanting into the substrate.

For intensive multiplication of Spathiphyllum $2 \mathrm{mg} / \mathrm{L} \mathrm{BA}$ was used in three successive subcultures. Since the 4th subculture this BA concentration led to a decrease in the number of high-grade shoots. Therefore the content of BA was lowered to $0.5-1 \mathrm{mg} / \mathrm{L}$ for one or two subcultures. 


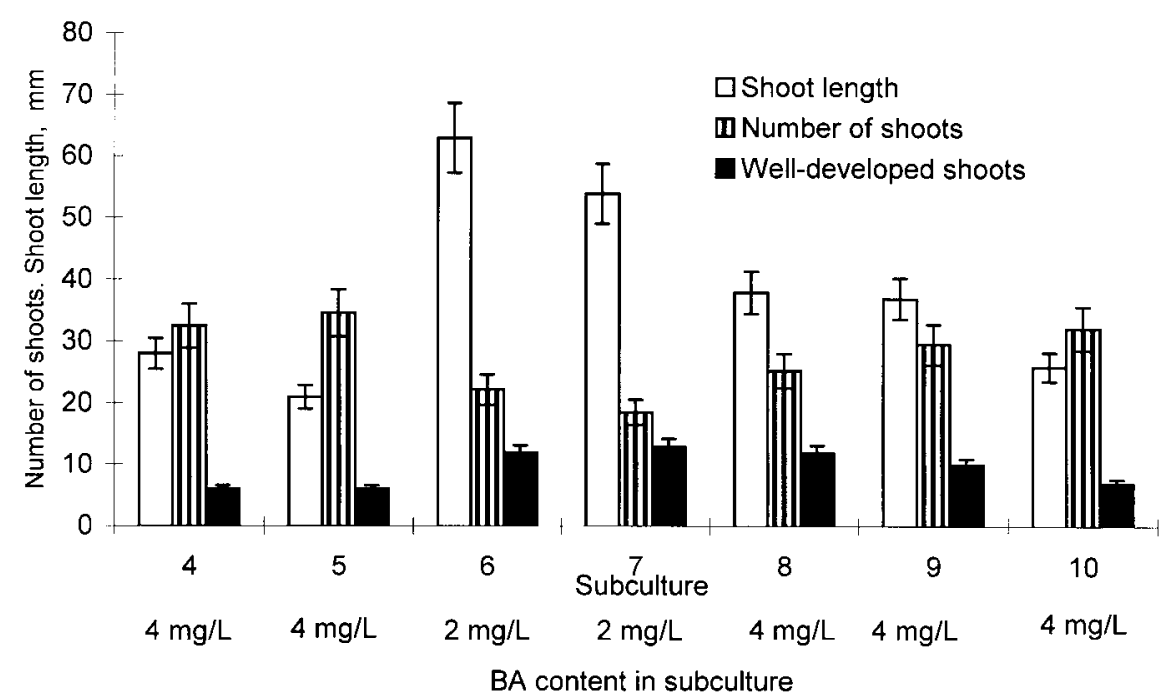

Fig. 3. Number and length of Philodendron tuxlanum shoots depending on the subculture (8 weeks each) and BA content of the medium. Error bars show the standard error of the mean.

Banana (Musa sp.) was propagated by tissue culture on media containing 5-10 mg/L BA. However, beginning with the 6th subculture, the multiplication rate started to increase rather quickly with a simultaneous reduction of shoot length. In the 10th subculture, the multiplication rate was 17, the shoot length reaching only $0.7-1.0 \mathrm{~cm}$ (duration of the subculture 4 weeks). Such shoots were not fit for rooting. Even at high concentrations of BA in the media, no vitrification of banana shoots was observed. To make use of the high shoot multiplication potency of banana elongation of shoots is needed. For this purpose, shoots are transferred as small clumps onto the elongation medium. In 3-4 weeks mostly rooted plants 5-7 cm long, suitable for immediate planting, are obtained.

\section{DISCUSSION}

The plants studied fall into three groups according to the cytokinin most suitable for their propagation.

1. Plants whose multiplication on BA media is not recommended (gerbera). Even relatively low BA concentrations in the media result in vitrification. Both BA itself and excess of moisture in the growing vessel inside the dense foliage of the clump may cause vitrification (Dillen \& Buysens, 1989; Bouza et al., 1992). Maintenance of a high uniform level of $\mathrm{K}$ in several subsequent subcultures may lead to the same result. Therefore, $\mathrm{K}$ content must be decreased gradually during 
long-term culture. However, this is not sufficient for a successful long-term propagation. The culture begins to stunt and to vitrify.

In the case of a number of plants this phenomenon has been related to the accumulation of salts, particularly ammonium ion, in the culture. Stunting can still not be explained by the mere accumulation of $\mathrm{NH}_{4}{ }^{+}$in gerbera culture as it occurred also during long-term culture on double Knop medium containing no ammonium salts. In the micropropagation of strawberry plants, Boxus (1974) recommends using Knop medium combined with MS microelements. It does not contain $\mathrm{NH}_{4}{ }^{+}$. Piagnani \& Eccher (1988) showed that plants became chlorotic during long-term propagation in $\mathrm{NH}_{4}{ }^{+}$-free media. Therefore ammonium salts had to be added at the last (rooting) stage of micropropagation. Our experiments have shown that when gerbera is grown on double Knop medium, its leaves decrease and become chlorotic (unpublished results). On media lacking $\mathrm{NH}_{4}{ }^{+}$ salts, chlorosis and reduced multiplication of other plants has also been observed (Snir, 1982; Faria \& Sequira, 1997). We suggest that in the case of gerbera a general rise in salt concentration in the culture is the causative agent. For that reason the shoots of gerbera have to be transferred onto media of lesser salt content from time to time.

2. Plants that may be multiplied on media containing either BA or preferably $\mathrm{K}$ (Cordyline, Dracaena, Dieffenbachia). The reason for the preference of $\mathrm{K}$ is that its content in the multiplication medium may be varied within a larger range without an excessive proliferation accompanied by shortening and vitrification of shoots. Moreover, K does not decrease the rooting of shoots. This allows propagation of the culture most intensively if necessary.

3. Plants that do not develop vitrification at the employed concentrations of BA in the multiplication media (Philodendron, Spathiphyllum, Musa). BA concentrations exceeding the optimum level to some extent do not cause vitrification. However, they lead to an excessive multiplication of the culture. BA does not decrease the rooting of banana. Shoots of banana even failed to produce roots or produced stunted, unsatisfactory roots on a medium without BA or $\mathrm{K}$ (Wong, 1986). This phenomenon, together with the subsequent transfer onto the elongation medium, may be used for very intensive propagation of the culture. As BA tends to accumulate in plant tissues, its concentration in the multiplication medium has to be reduced from time to time.

Many controversial results concerning the role of cytokinins, especially BA, in rhizogenesis have been published. Application of BA, even in optimum concentrations, can inhibit subsequent root initiation (Bressan et al., 1982; Werbrouck et al., 1995). For this reason, it is advisable to employ an elongation medium before the rooting stage or to lower the concentration of cytokinins during the last subculture before transferring the shoots onto the rooting medium. Obviously some endogenous level of cytokinins in the shoots is necessary for maintaining the vigour of the cultured shoots in rooting media (Bressan et al., 1982). In the study of Nemeth (1979) with Prunus cerasifolia, P. avium, 
P. persica $\times$ amygdalus, and Cydonia oblonga and in a work with Malus pumila (Sriskandarajah et al., 1982) exogenous BA $\left(10^{-6} \mathrm{M}\right)$ added to the rooting medium favoured root formation.

\section{REFERENCES}

Bouza, L., Jacques, M., Mazière, Y. \& Arnaud, Y. 1992. In vitro propagation of Prunus tenella Bach. cv. 'Firehill': Control of vitrification; increase of the multiplication rate and growth by chilling. Sci. Hort., 52, 145-155.

Boxus, P. 1974. The production of strawberry plants by in vitro propagation. J. Hort. Sci., 49, 209210.

Bressan, P. H., Kim, Y.-J., Hyndman, S. E., Hasegawa, R. M. \& Bressan, R. A. 1982. Factors affecting in vitro propagation of rose. J. Amer. Soc. Hort. Sci., 107, 979-990.

Corchete, M. P., Fenning, T., Gartcand, L. S. \& Valle, T. 1997. Micropropagation of Ulmus species (Elms). In Biotechnology in Agriculture and Forestry. 39. High-Tech and Micropropagation, V (Bajaj, Y. P. S., ed.), pp. 381-392. Springer-Verlag, Berlin-Heidelberg.

Declerck, V. \& Korban, S. S. 1995. Shoot regeneration from leaf tissues of Phlox paniculata L. J. Plant Physiol., 147, 441-446.

Dillen, W. \& Buysens, S. 1989. A simple technique to overcome vitrification in Gypsophila paniculata L. Plant Cell Tiss. Organ Cult., 19, 181-188.

Evaldsson, I. E. \& Welander, N. T. 1985. The effects of medium composition on in vitro propagation and in vitro growth of Cordyline terminalis cv. Atoom. J. Hort. Sci., 60, 525530.

Faria, J. L. C. \& Sequira, J. 1997. In vitro control of adventitious bud differentiation by inorganic medium components and silver thiosulphate in explants of Passiflora edulis f. flavicarpa. In Vitro Cell. Develop. Biol. Plant, 33, 209-212.

Jámbor-Benczúr, E. \& Márta-Riffer, A. 1990. In vitro propagation of Philodendron tuxlanum Bunting with benzylaminopurine. Acta Agron. Hung., 39, 341-348.

Knop, W. 1865. Quantitative Untersuchungen über die Ernahrungsprozesse der Pflanzen. Landwirtsch. Vers. Stn., 7, 93-107.

Linsmaier, E. M. \& Skoog, F. 1965. Organic growth factor requirements of tobacco tissue cultures. Physiol. Plant., 18, 100-127.

Maene, L. J. \& Debergh, P. C. 1985. Liquid medium additions to established tissue cultures to improve elongation and rooting in vivo. Plant Cell Tiss. Organ Cult., 5, 23-33.

Murashige, T. \& Skoog, F. 1962. A revised medium for rapid growth and bio-assays with tobacco tissue cultures. Physiol. Plant., 15, 473-497.

Nagakubo, T., Takaichi, M. \& Oeda, K. 1997. Micropropagation of Allium sativum L. (Garlic). In Biotechnology in Agriculture and Forestry. 39. High-Tech and Micropropagation, $V$ (Bajaj, Y. P. S., ed.), pp. 3-19. Springer-Verlag, Berlin-Heidelberg.

Nemeth, E. 1979. Benzyladenine-stimulated rooting in fruit-tree rootstocks cultured in vitro. $Z$. Pflanzenphysiol., 95, 389-396.

Norton, M. E. \& Norton, C. R. 1986. Change in shoot proliferation with repeated in vitro subculture of shoots of woody species of Rosaceae. Plant Cell Tiss. Organ Cult., 5, 187197.

Piagnani, C. \& Eccher, T. 1988. Factors affecting the proliferation and rooting of chestnut in vitro. Acta Hort., 227, 384-386.

Shibli, R. A., Smith, M. A. L. \& Nasr, R. 1997. Iron source and cytokinin mitigate the incidence of chlorosis and hyperhydratation in vitro. J. Plant Nutr., 20, 773-781. 
Snir, I. 1982. In vitro propagation of sweet cherry cultures. HortScience, 17, 192-193.

Sriskandarajah, S., Mullins, M. G. \& Nair, Y. 1982. Induction of adventitious rooting in vitro in difficult-to-propagate cultivars of apple. Plant Sci. Lett., 24, 1-9.

Vardja, R. 1997. Dekoratiivtaimede optimeeritud paljundamine koekultuuris. M.Sc. thesis. Tartu.

Vardja, R. \& Vardja, T. 1995. Mass propagation of the dwarf rose cultivar 'Victory Parade'. Proc. Estonian Acad. Sci. Biol., 44, 119-123.

Voyatzi, C. \& Voyatzis, D. G. 1989. In vitro shoot proliferation rate of Dieffenbachia exotica cultivar 'Marianna' as affected by cytokinins, the number of recultures and the temperature. Sci. Hort., 40, 163-169.

Werbrouck, S. P. O., van der Jeugt, B., Dewitte, W., Prinsen, E., Van Onckeken, H. A. \& Debergh, P. C. 1995. The metabolism of benzyladenine in S. floribundum Scott 'Petite' in relation to acclimatization problems. Plant Cell Rep., 14, 662-665.

Wong, W. C. 1986. In vitro propagation of banana (Musa spp.): Initiation, proliferation and development of shoot-tip cultures on defined media. Plant Cell Tiss. Organ Cult., 6, 159166.

\title{
TSÜTOKINIINI TÜÜBI JA KONTSENTRATSIOONI NING ÜMBERISTUTUSTE ARVU MÕJU MÕNEDE DEKORATIIVTAIMEDE PALJUNEMISKOEFITSIENDILE
}

\author{
Rael VARDJA ja Tõnis VARDJA
}

On käsitletud mõningate dekoratiivtaimede pikaajalist mikropaljundust koekultuuris. Katses olnud taimed jagati kolme gruppi vastavalt nende tundlikkusele tsütokiniinide bensüüladeniini (BA) ja kinetiini (K) suhtes. Esimeses rühmas on taimed, mille paljunduseks BA ei sobi (gerbera sordid). Siiski tuleb ka gerbera pikaajalisel paljundamisel K-ga söötmetel järk-järgult vähendada $\mathrm{K}$ sisaldust söötmes. Pärast kaheksandat või üheksandat ümberistutust viiakse võsud puhkusesöötmele, millele on lisatud $\mathrm{K} 0,1 \mathrm{mg} / \mathrm{l}$ ja indolüülatsetaati $1,0 \mathrm{mg} / \mathrm{l}$. Teist rühma - Cordyline, Dracaena ja Dieffenbachia - võib paljundada nii BA kui ka $\mathrm{K}$ söötmetel, kuid kohasem on $\mathrm{K}$, kuna selle sisaldust söötmetes võib varieerida (0,5-4 mg/l), ilma et tekiks ebasoovitavaid nähte. Kolmanda rühma taimede paljunduseks sobib BA, kuna isegi küllaltki suure BA $(5 \mathrm{mg} / \mathrm{l})$ sisalduse puhul paljundussöötmetes ei teki klaasistumist (Philodendron, Spathiphyllum ja Musa). Juurutamiseks sobivaimate võsude saamiseks tuleb iga viienda-kuuenda ümberistutuse järel vähendada BA sisaldust paljundussöötmes kaks kuni kolm korda. 